\title{
The language of symbols in prehistoric Anatolia
}

\author{
Jak Yakar \\ Sonia and Marco Nadler Institute of Archaeology, Tel Aviv University, Israel \\ yakar@post.tau.ac.il
}

\begin{abstract}
The conceptual and ritual background of symbolism in the prehistoric art of Anatolia should be investigated within the socio-economic background of the pertinent Neolithic and Chalcolithic societies. Since the adoption of farming did not totally replace the more traditional modes of subsistence, it is doubtful that the supernatural world-order envisaged by earlier hunter-gatherers would have been entirely altered by new spiritual concepts.
\end{abstract}

IZVLEČEK - Konceptualno in ritualno ozadje simbolizma prazgodovinske umetnosti v Anatoliji moramo raziskovati znotraj socialno ekonomskega družbenega okolja neolitskih in bakrenodobnih družb. Ker poljedelstvo ni povsem nadomestilo tradicionalnih načinov pridobivanja hrane, tudi novi duhovni koncepti verjetno niso popolnoma spremenili pogledov prvotnih lovcev in nabiralcev na nadnaravno ureditev sveta.

KEY WORDS - Anatolia, Neolithic, Chalcolithic, symbolism, shamanism, decoration

Elements of conceptual symbolism observed in the prehistoric art of Anatolia should be analyzed within the context of the social and economic characteristics of the Neolithic and Chalcolithic societies. Parallel to the agriculture, and cattle and sheep rearing that characterize this era, forms of more traditional economic strategies based on herding, seasonal hunting and gathering continued at different levels of intensity among most sedentary communities. Since the adoption of farming did not totally replace earlier modes of subsistence, it is somewhat questionable that the supernatural world-order envisaged by earlier hunter-gatherers would have been entirely altered by new spiritual concepts that emerged during the ascendancy of agriculture. In fact, in the Neolithic and Early Chalcolithic repertories of symbols incorporated in decorative compositions applied on ceramics, pottery and other mediums, there are certain motifs that seem to have their origins in earlier periods. The prehistoric rock drawings from the Latmos area in western Turkey (Peschlow-Bindokat 1995; 2003) clearly demonstrate that painted female figures, probably symbolizing fertility/proliferation, retained their meaning for thousands of years (Figs. 1-2). In this case, there seems to be a clear connection between the springs in the general area of the painted rock outcrops and the male and female figures, represented individually, in couples or groups. Equally significant is the fact that the tradition of painting these types of anthropomorphic figures, some perhaps going back to the Late Epipaleolithic/Early Neolithic, continued well into the Early Chalcolithic period. In this case, this could suggest that the tradition of seasonal or periodic gatherings for conducting communal fertility-related rituals may have originated in the period before farming became the principal subsistence economy of most sedentary communities in prehistoric Anatolia.

Curiously enough, even among some contemporary traditional communities in the rural countryside of Anatolia, rituals for the purpose of invoking rain are sometimes called "the bride", "bride of rain", and "bride of the sky" (Acrpayaml 1978.11). Thus, references to a young woman/young bride in connection with sources of water and certain fertility-related natural events continue to this day.

Additional symbolic motifs painted on rock surfaces include hands, feet or fingers, as well as a number 
of enigmatic linear drawings. This type of cult-related ritual symbolism also occurs on some of the Cyatalhöyük wall paintings (Figs. 2b, 8a-8b) and Hacllar-type ceramics. Originally, all these symbolic forms may well have belonged to the repertory of deeprooted semantic signs used by ritual practitioners, that is, shamans $\mathbf{1}$.

To return to the question of continuity pertaining to concepts of the supernatural, some scholars maintain that Neolithic subsistence economies largely based on food production would have changed the cosmic logic of earlier periods. The new understanding of the universe would have consisted of human and social logics overlaying old concepts (Bischoff 2002.240). In other words, in the cosmology of early farming societies experimenting with agriculture while still maintaining a measure of hunter-gathering, the earth would have been considered the source of all life's elements. Along this line of thinking, it is assumed that in configurations of the cosmos as perceived by shamans, figures of women, leopards, bulls and rams could have symbolized the earth, vultures the sky, and snakes, the underworld (Bischoff 2002.241-242). What one should ask is to what extent "cosmic conflicts" such as storms, earthquakes, lightning, forest and bush fires, the eruption of volcanoes and so on as experienced by prehistoric farmers were explained as originating from the earth and represented in symbolic art forms.

The Neolithic and Early Chalcolithic societies of Anatolia, like their contemporaries in neighboring regions, created locally distinct ornamental motifs applied to a range of utilitarian and non-utilitarian artifacts. In the decorated ceramic assemblages of the late seventh to the late sixth millennia $\mathrm{BC}$ in Central Anatolia, one can find some of the best illustrations of symbolism. Since rituals are generally symbolic in character, most scholars have considered symbolism in prehistoric art to be the artistic expression of spiritual beliefs 2 .

The 'Hacllar-type painted wares of Pisidia, or those of Can Hasan II/Çatalhöyük-West designs found in the Konya plain demonstrate a regional conformity in the use of space, as well as the combination of motifs into pre-conceived patterns. In addition, there are also non-repeated, unusual, designs that fall in-

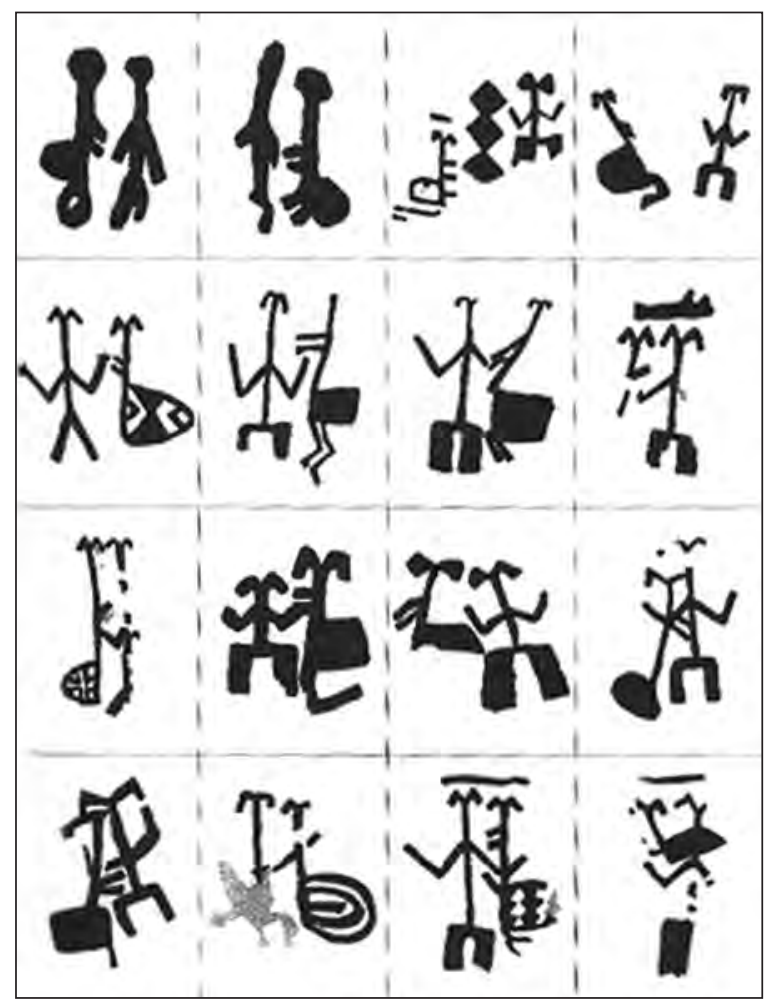

Fig. 1. Latmos rock paintings (after PeschlowBindokat 2003).

to the category of an 'imagined' or 'fantastic' style, as seen in some of the Hacilar painted pottery (Figs. 3-4). The type and arrangement of geometric, linear and other designs on Neolithic-Early Chalcolithic pottery (Figs. 5-7a), including seals (Fig. 7b) and other utilitarian and non-utilitarian artefacts from certain regions of Anatolia, share certain conceptual similarities with equivalent assemblages from Southeast Europe. Consequently, some of us researching the manifestation of spiritualism in the prehistoric art of Anatolia also presume that certain types of decoration applied to various media may have had semantic content (Yakar 2003). If so, we may speculate that individual or group of motifs arranged in different configurations and contexts would have expressed different things. It is rather doubtful, however, that vessels decorated with symbolic designs would have been considered animated or even sacred when not used in rituals. While we may propose that certain compositions could have possibly conveyed visions, experiences, observations and messages of a spiritual, philosophical or mundane nature, our ability to decode the sign value of such abstract mo-

1. For more details on symbolism in shaman ceremonies, see Bischoff (2002.240-244). For more general studies on symbolism and contextual meaning, see Hodder (1982; 1987; 1989; 1995).

2. Verhoeven (2002.235) proposes a new model for the analysis of ritual, stressing the importance of symbolism especially, since many rituals are characterized by an elaborate use of symbols. 


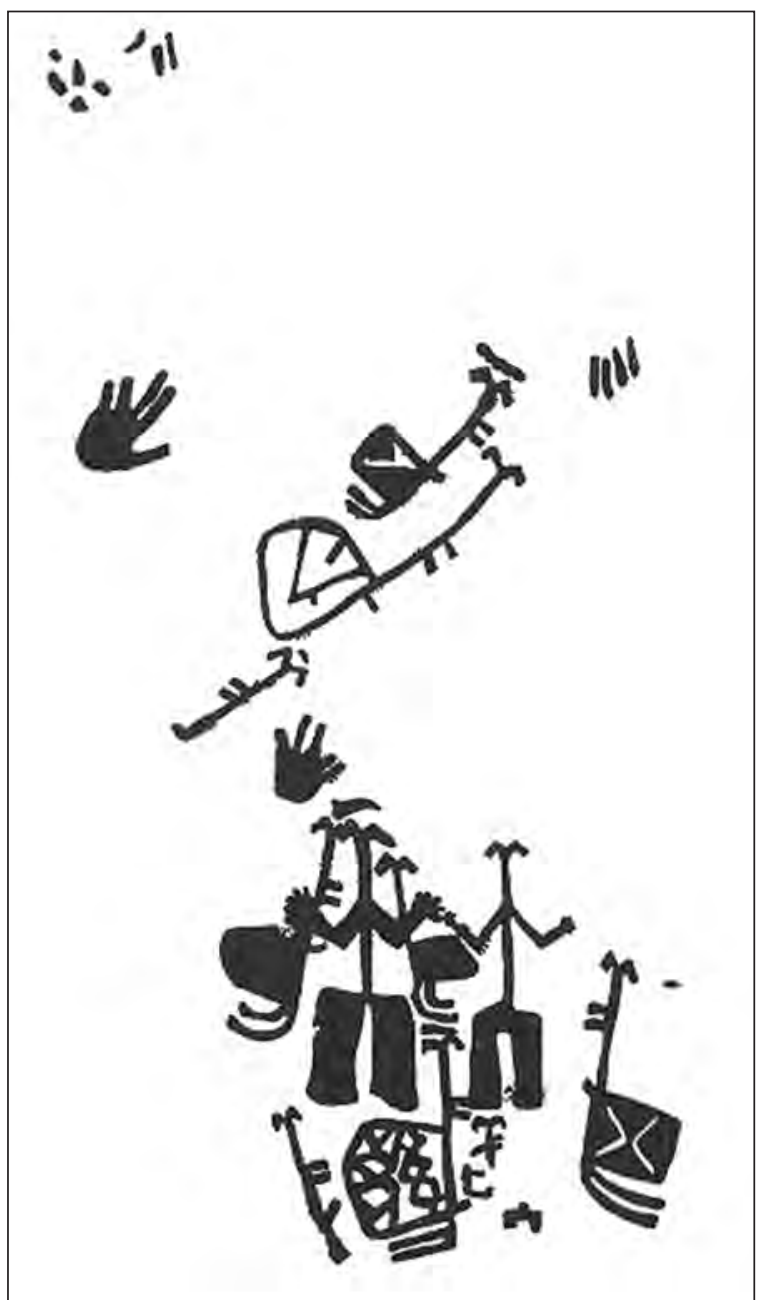

tifs is very limited. Moreover, some geometric/linear compositions on wall paintings or ceramics could have been abstract renderings of visions experienced during altered states of mind and at least partly retained in the memory bank 3 .

Our south-east European colleagues have long been trying to "decipher" the meanings of certain abstract motifs and ornamental compositions decorating prehistoric ceramics and a variety of objects. A recently published monograph on Early Symbolic Systems for Communication in Southeast Europe compiled and edited by Lolita Nikolova (2003) is among the innumerable and creative attempts at tackling this problematic issue. One point of broad agreement has to do with the conceptual treatment of material culture among prehistoric communities. We can assume, on the basis of shamanic world views, that in prehistoric societies, too, certain artefacts, because of their shapes and decorations, may have been per-

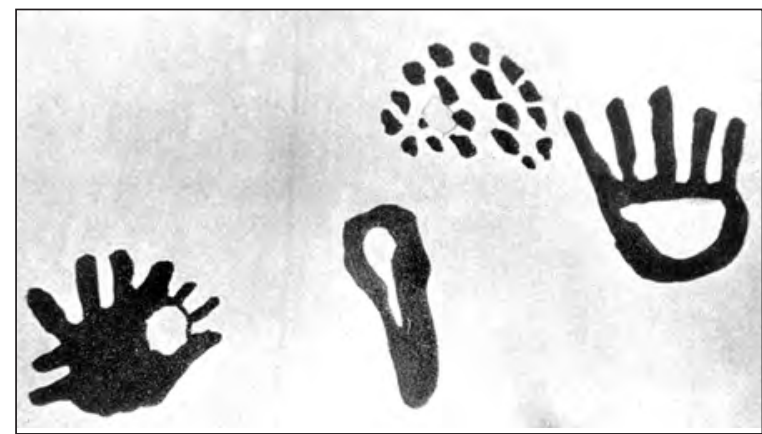

Fig. 2a (left). Latmos rock paintings (after Peschlow-Bindokat 2003).

Fig. $2 b$ (up). Symbols with unknown meanings on a wall painting from Çatalhöyük-East.

ceived charged with life forces, which on certain occasions demanded special attention. Such artefacts may have served as symbolic media of communication between the human and spirit domains.

A second point of agreement concerns the shamanic concept of a tripartite universe that might have existed in the Neolithic societies' understanding of cosmology. Nevertheless, it is rather difficult to construe the cosmological iconography of prehistoric societies by attributing symbolic values to geometric and linear compositions executed on a range of utilitarian and non-utilitarian artefacts. The diffusion of such material culture artefacts to more distant neighbouring territories brought about the transmission of symbols with ritual and cosmogological semantics to other cultures. The question is, did such exported or borrowed ornamental compositions keep their original symbolic values?

Constantly repeated ornamental schemes are proof of adherence to culturally and, perhaps, socially significant codes of decoration. Beyond this third point of general agreement, there is little consensus regarding the decoding of prehistoric symbols. For example, it is difficult to substantiate that a certain decorative design retained its semantic or symbolic value over many generations. Another problem relates to symbolic values attached to geometric signs or linear/curvilinear motifs. For instance, did double spirals or entwined snakes depict expressions of male and female unity?

We all agree that explaining the acquisition of particular imagery in prehistoric art is not a simple mat-

3. Referring to geometric patterns such as multiple arcs, zigzags, and notches incised on the surface of some Upper Paleolithic period statuettes in Germany, Dowson and Porr suggest that these motifs may have hallucinatory origins found in shamanic art (2001.Fig. 11.6). 
ter. In particular, distinguishing between a multitude of what we term encoded messages of a spiritual and conceptual nature and symbolic expressions of a social nature is an almost impossible task. Nonetheless, there is no reason to doubt that in some cases, behind each individual motif or composition there would have been an impulse to express a certain idea or observation, or even a spiritual insight. In other words, behind their particular aesthetic effect lay encoded expressions of ingrained beliefs, especially those pertaining to the visualization of supernatural and cosmic worlds. We may further presume that certain symbolic spiritual motifs applied to receptacles or objects would have prescribed and conveyed appeasing messages to ancestral spirits who might have been assumed to be ever-present among the living.

Abstaining from such a speculative debate may be wise. However, this will not advance our efforts to grasp how the realms of the "profane" and "spiritual" or the "living" and "dead" could had been understood or referred to in prehistoric societies. Among contemporary non-literate ethno-cultural entities, the realms of the dead and living constantly interact.

Therefore in decoding prehistoric motifs from Anatolia, recourse to ethnographic analogies could provide a better understanding of the significance of symbolism. No matter how logical, attractive and persuasive the decoding of certain signs may be, their assumed meanings are very difficult to substantiate even with the help of ethnographic analogies4.

In discussing the use of prehistoric symbolic art in various media, we should also consider designs applied to clothes and tattoos. Tattooing and other forms of skin decoration by painting, skin penetration or scarification probably known in the distant past still exist among many cultures in the world. For example, the oldest direct evidence of ancient tattooing is found in the form of a few dots and lines on Egyptian and Peruvian mummies. While most of these may have been markers of social rank, others were probably considered to have protective, preventive, and curative properties. A few may have also carried cryptic messages and pronouncements of a spiritual nature. However, so far frozen Scythian burials provide the best examples of symbolism in ancient tattooing. The example of the Pazaryk nomad chieftain in the Siberian Altai Mountains, dating from around $400 \mathrm{BC}$, is one of the better-known examples (Rudenko 1970). In this case, the tattoos

4. Leshtakov suggests that ornamental compositions without 'ritual and cosmological semantics' are constructed mainly from crosses, circles, swastikas, rhombuses, meanders, spirals, and bucranium motifs, in various versions and combinations. Following this line of thinking, Todorova is convinced that multi-level symbols are traditionally associated with ideas of birth and growth, the change of seasons, the four cardinal points, and eternal movement (in Nikolova 2003). 


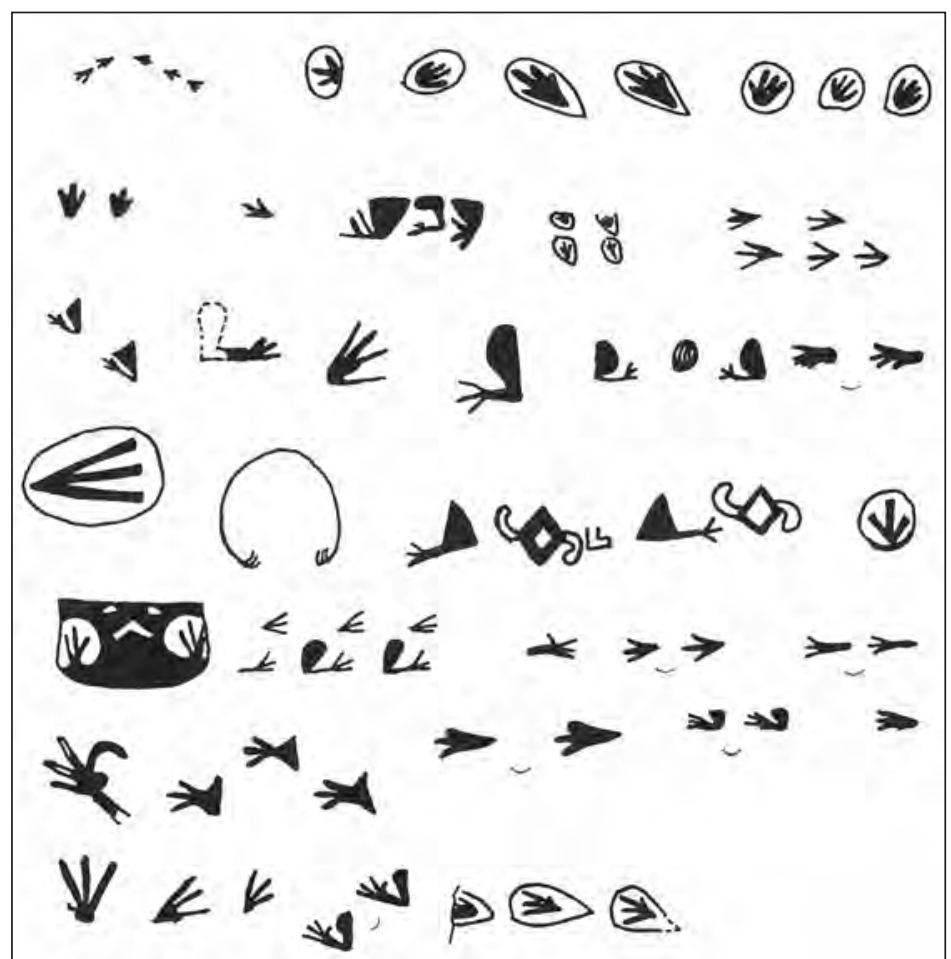

Fig. 4. Painted motifs probably with symbolic values. Early Chalcolithic pottery from Hacular (after Mellaart 1970). or bird's head terminals are part of a rich repertory of supernatural forces long present in the iconographic art of the ancient Near East. Another Pazyryk burial chamber in the no-man's-land between Russia and China produced some 11 years ago the famous mummy known as the "Ice Maiden of the Gorno Altai". Apparently no ordinary woman, perhaps a shaman, her body revealed ornamental tattoos on the shoulder and right hand thumb, perhaps identifying her elevated rank in Scythian society (Fig. 12). We may presume that other, simpler tattoos, including those not visible, would have likely served therapeutic and spiritual purposes. Indeed, the man from Kurgan 2 of the Pazyryk necropolis has skin marks which are believed to represent traces of therapeutic treatment. A line of only three pinpoints to the right matches a vertical line consisting of eleven pinpoints to the left of the lumbar spine. In addition, an arc-shaped line of six pinpoints was tattooed on seem to have been prescribed socially and/or ritually. These were no doubt outward signs of the ethnic, political and religious identity of the individual. Certain ornate visible tattoos could have served as indicators of status, descent, group membership, and so on. Among them, hybrid compositions such as a lion-griffin with a long tail twisting into a snake's his right ankle. The correspondence between the therapeutic tattoo marks of the nomad ruler and those on the Iceman (named Ötzi) from Paso di Tisa on the Italian Tyrol (Tisenjoch or Hauslabjoch) dated to the late fourth millennium $\mathrm{BC}$ is striking 5 . On the body of the Iceman these were applied by puncturing the skin with a bone awl and using powdered

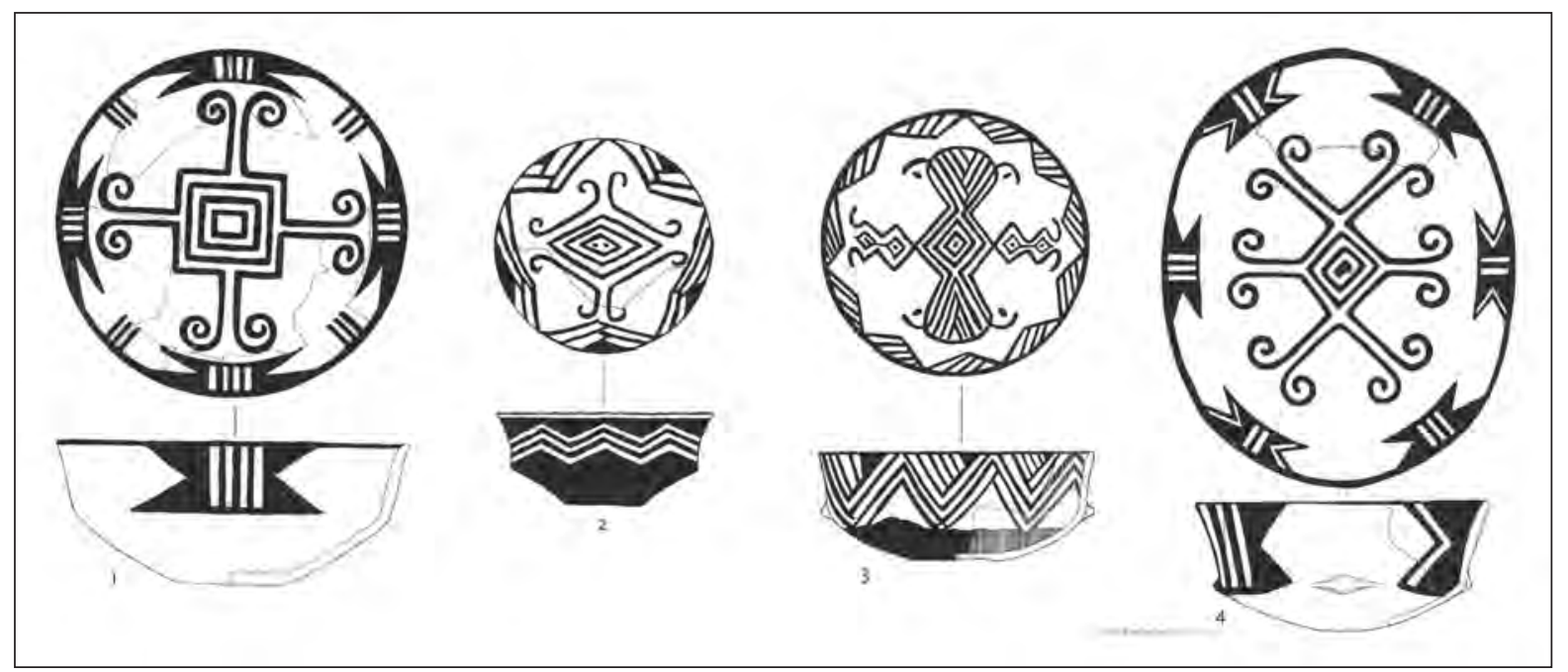

Fig. 5. Hacılar. Early Chalcolithic pottery painted with linear designs (after Mellaart 1970).

5. The tattoos on the Iceman's body are numerous: 1) four groups of lines to the left of the lumbar spine; 2) one group of lines to the right of the lumbar spine, 3) a cruciform mark on the inside of the right knee, 4) three groups of lines on the left calf, 5) a small cruciform mark to the left of the Achilles tendon, 6) a group of lines on the back of the right foot, a group of lines next to the right outer ankle, and 7) a group of lines above the right inner ankle (Splinder 1994). 
charcoal mixed with saliva or water that produced a blue tint (Splinder 1994). No particular pattern was discerned arrangement of the tattooed marks 6 . In addition to a small, cruciform-like design that was tattooed twice on the left of the Achilles tendon and on the inside of the right knee, short lines were applied on most other body parts, especially limb joints (Fig. 11). Considering the wear-and-tear signs at the knee joints and both ankle joints, and signs of osteochondrosis and also a slight spondylosis on the lumbar spine, the tattoos were therapeutic in purpose.

Returning to decorated ceramic and stone vessels, seals, talismans, or even occasionally the walls of domestic and cult buildings in Neolithic and Chalcolithic Anatolia, we are faced with the task of decoding their linear, curvilinear or geometric compositions. Ethnographic data pertaining to the use of symbolism in art as practiced by distinct ethno-cultural entities, especially those that once practiced or still practice shamanism, could help to explain deep-rooted notions encoded in ornamental schemes. Ethnographic analogies suggest that some of the highly visual and evocative symbols in prehistoric art may have referred not only to cosmology and the supernatural, but probably to profane issues also.

Since, Western and Central Asiatic tapestries are rich in symbolism, certain abstract motifs seen on traditional nomadic kilims from central and eastern Anatolia require a closer look. It is important to point out that most of these designs are also found on $\mathrm{ki}$ lim decorations originating in Transcaucasia and Caucasia. More than any other medium, these ornamental compositions best illustrate the semantics of symbolism in conceptual art. The repertory of motifs, their arrangement, colours and weaving techniques vary slightly from one geo-cultural or ethno-cultural entity to another. The fact that certain motif
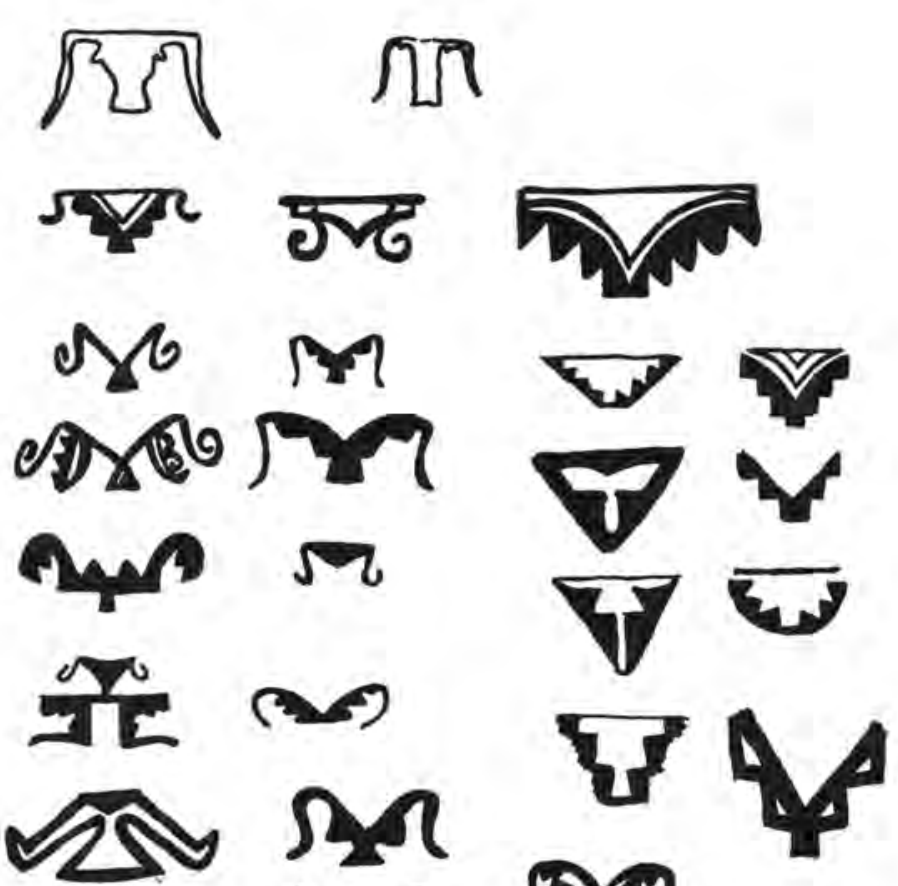

Mn
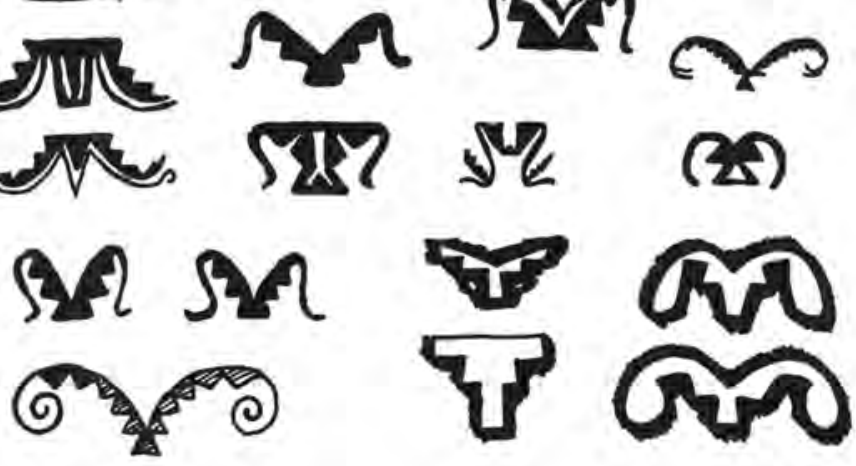

Fig. 6. A variety of bucranium motifs on some Early Chalcolithic painted pottery (after Mellaart 1970).

and colour compositions are highly characteristic of certain localities or regions once inhabited by culturally distinct tribal groups indicates that also in the distant past ornamental compositions such as those on ceramics may have also been used for ethno-cultural group identity.

The infinite range of motifs on kilim-type tapestry shows some variation in design and composition according to the ethno-cultural identity of the people that produce them. Therefore, stylized nomadic motifs seen on kilim-type tapestries and on seals are designs indicating ethno-cultural identity. Moreover colour and design compositions, and particular weaving techniques are considered the property of geo-

6. The groups of lines to the left of the lumbar spine are arranged vertically, starting from top down with a group of four, followed by two groups of three, followed in turn by a gap, and finally by another group of four. A group of four line tattoos was applied to the right of the lumbar spine at exactly the same height as the gap on the left-hand side. 


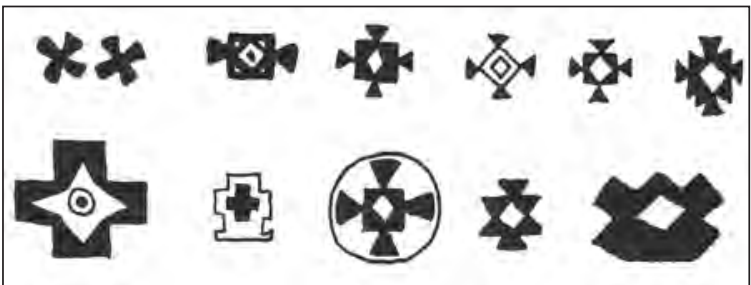

Fig. 7a. Star or rosette-like motifs with unknown symbolic values applied on Hacilar Early Chalcolithic painted pottery (after Mellaart 1970).

culturally defined groups. Although each woven motif has a precise meaning, the original notions, stories, or messages conveyed by their combinations or pattern arrangements barely survive in the collective memory of those who continue to produce them. Although some groups consider certain motifs and designs as their own, attributions based solely on motifs could sometimes be misleading, since others frequently borrow them to create their own distinct designs. Therefore, the possibility that in the distant past certain motifs could have been adopted, with or without modification, cannot be ruled out. In such cases, we may assume that the resultant motif or pattern could have acquired another meaning.

In geometric design, which is a very old tradition, motifs are highly stylized natural subjects composed of vertical, diagonal and horizontal lines. Curvilinear and floral designs, on the other hand, are more recent; they do not appear on Islamic rugs until the early $16^{\text {th }}$ century.

On old Chinese and Tibetan rugs and carpets, artistic inspiration from the beginning derived from re-

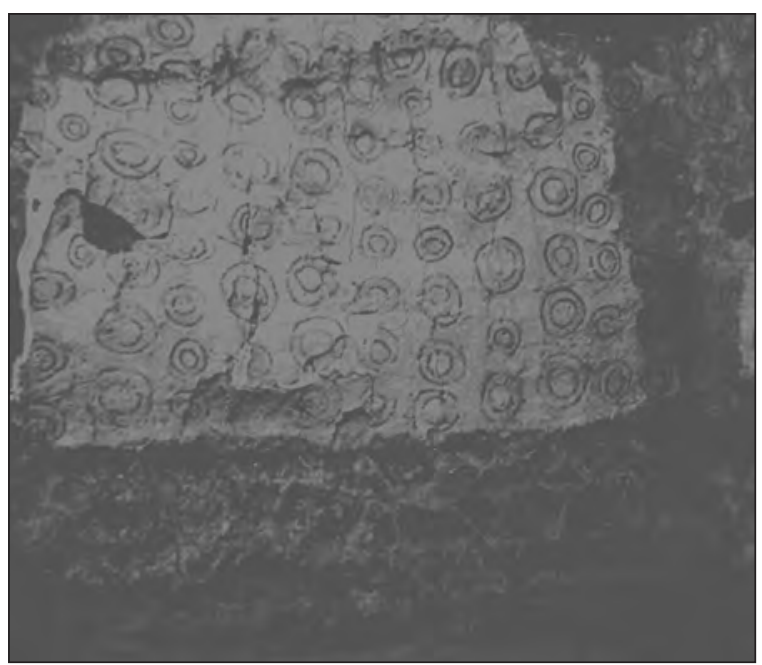

Fig. 8a. Concentric circles and triangular forms painted on walls. Çatalhöyük-East (after Yakar 1991).

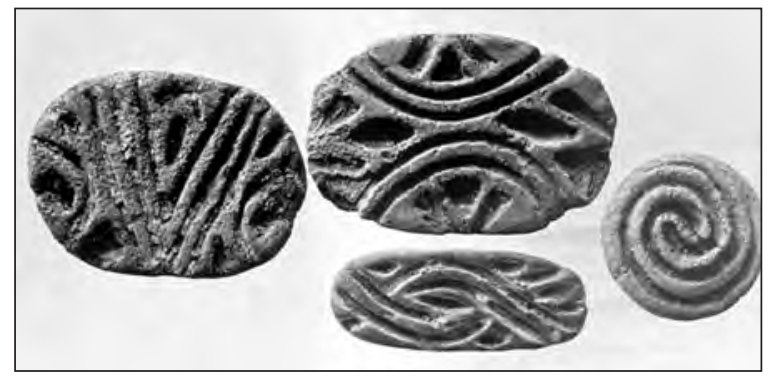

Fig. 7b. Linear designs on seals from ÇatalhöyükEast (after Mellaart 1962).

ligious doctrines such as Taoism and Buddhism. Therefore, the significance of the design is far from obscure, since almost every motif has a well-known symbolism. Messages conveyed relate to "happiness', "longevity and good things", "happy marriage", "purity" "conjugal happiness" "fertility", and "power and adaptability" (Bamborough 1979.47). Although these Far Eastern symbols are quite different in form from those seen on oriental kilims, the substance of the desires and aspirations relayed by them are rather similar.

Motifs with semantic values can best be seen on nomadic kilim-type tapestries produced in a geographical belt extending from Anatolia to Central Asia in the east and the Balkans in the west. The decorative patterns on nomadic kilim and the stamp seals of the Yörük, Türkmen and Afşar tribal groups in Anatolia clearly demonstrate that particular arrangements of abstract motifs often relate to group identity. They are schematizations of elements taken from the natural environment, as well as representations of objects of daily use. Much like pictographic script, they are sometimes arranged in chang-

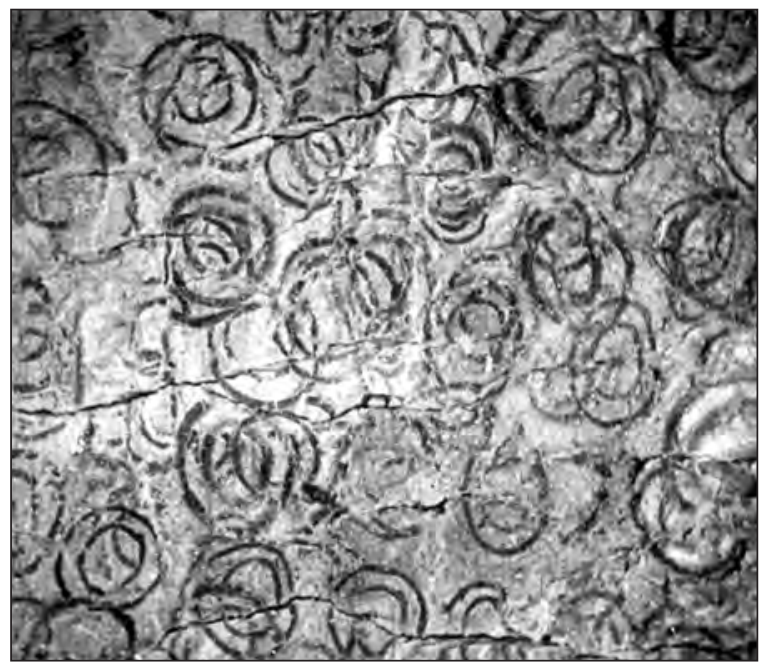

Fig. 8b. Concentric circles painted on a wall. Catalhöyük-East (after Yakar 1991). 
ing combinations to express different notions and emotions. Various arrangements and colour compositions among the Yörük, Türkmen and Afşar nomads, and settled nomads often carry messages and even express a certain sense of humor that is crucial in maintaining a peaceful and prosperous life in the tent and encampment. Since colours also have a significance of their own, they can alter the meaning of a motif (Durul 1987.52). Blue generally symbolizes hope, purple grief; and black and sometimes white are colours of mourning. Orange and red express life, love and the like. In many regions, green expresses "life purpose", "goal" etc.

The rich variety of abstract motifs on kilims comprises no fewer than five groups. In each group, the symbolic value of only a few motifs may have preserved their original definitions.

Humans are always stylized (Figs. 9-10). Human body parts, sometimes in pairs, are common in decorative schemes. While big ears symbolize wariness of eavesdroppers, the eye is considered to have a protective property against "evil".

Representations of women in highly stylized forms are particularly popular in traditional kilim decorations. There is a great variety of female figures, each naturally having a different meaning, and not only symbolizing the essence of "fertility" or "marital bond". Mature women are depicted with large hips, and married women with hands on their loins. Social and mental statuses such as pregnancy, insanity, or bizarre maidens, unmarried, or engaged girls, are emphasized by slightly different details and postures 7 .

Most representations of men symbolize strength and heroism. A particular design of a male with unnaturally formed legs depicts "mother's son" or "hantmoğlu" in Turkish (Durul 1987.26), and carries the message of "lacking in manly character/attributes" in other words, it refers to "feeble man".

Zoomorphic and entomological motifs include goat, sheep, dogs, turtle and a variety of birds. There are also figures that represent flocks and flocks on the move, such as flocks of geese and flocks of geese on the move, caged birds, fighting cocks, dogs' footprints, cats' ears, wolves' mouths, ears, teeth and spoor, foxs' ears, donkeys' ears, squirrel teeth, frogs, scorpions and flies. It is important to note that the

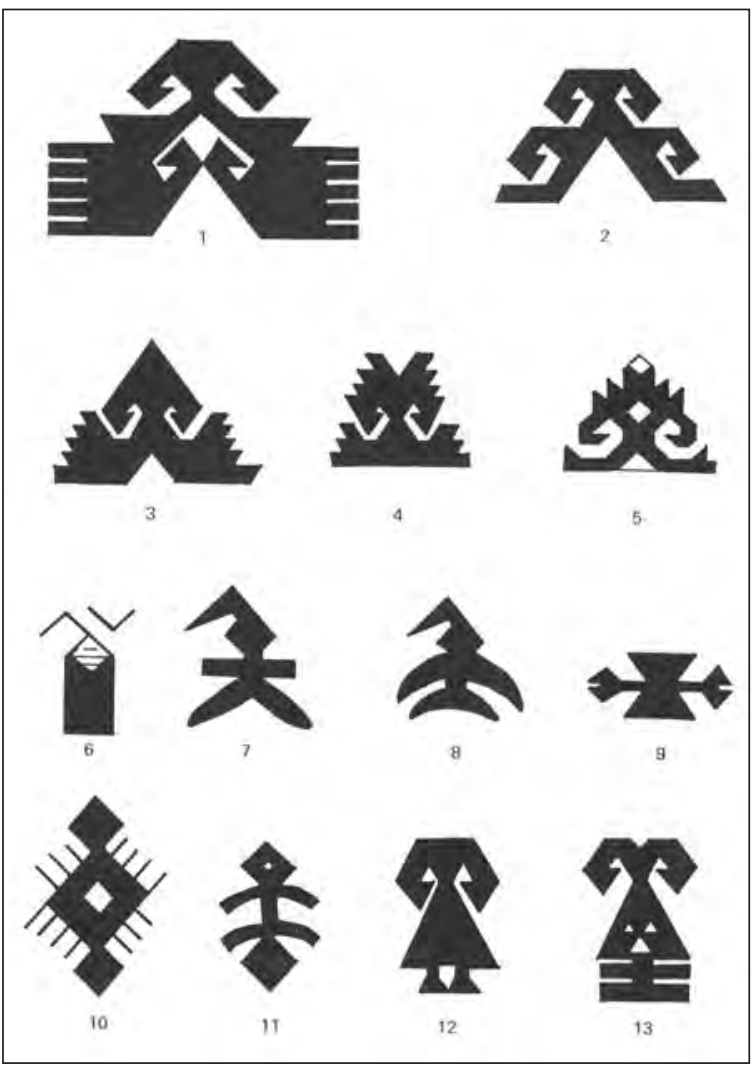

Fig. 9. Semantics of symbols - stylized female figures on Afşar, Turkmen and Yörük kilim (after Durul 1987): 1. Mature woman; 2. Young girl (Yörük symbol); 3. Young girl (Afşar symbol); 4. Young girl (Yörük symbol); 5. Young girl (Turkmen symbol); 6. Deranged woman; 7. Maiden (Yörük symbol: Eskişehir-Karakeçeli tribe); 8. Maiden (Yörük symbol: Eskişehir-Karakeçeli tribe); 9. Young girl (Turkmen symbol); 10. Untamed girl; 11. Maiden (Yörük symbol: Eskişehir-Karakeçeli tribe); 12. Young girl (Af̧̧ar symbol); 13. Young girl (Afş̧ar symbol).

dimensions of the motifs are not in proportion to the size of the subjects depicted. The abstract illustrations of whole animals and insects could depict the natural environment of the habitats occupied by these nomads. Moreover, these also illustrate the subsistence activities of the nomads, such as herding and so on, and dangers posed by wildlife. However, except for ram and scorpion heads, the original symbolic value of the body parts of animals remains largely an enigma. Ram heads stand for "brave rams", which in turn symbolize "bravery" or "a brave man" among the Afşar tribesmen. The scorpion head is a symbol of bad luck.

Flora constitutes the third group of representations. Like fauna, this group illustrates the natural envi-

7. For details and illustrations, see Durul (1987.23-24, 26-27, 41). 


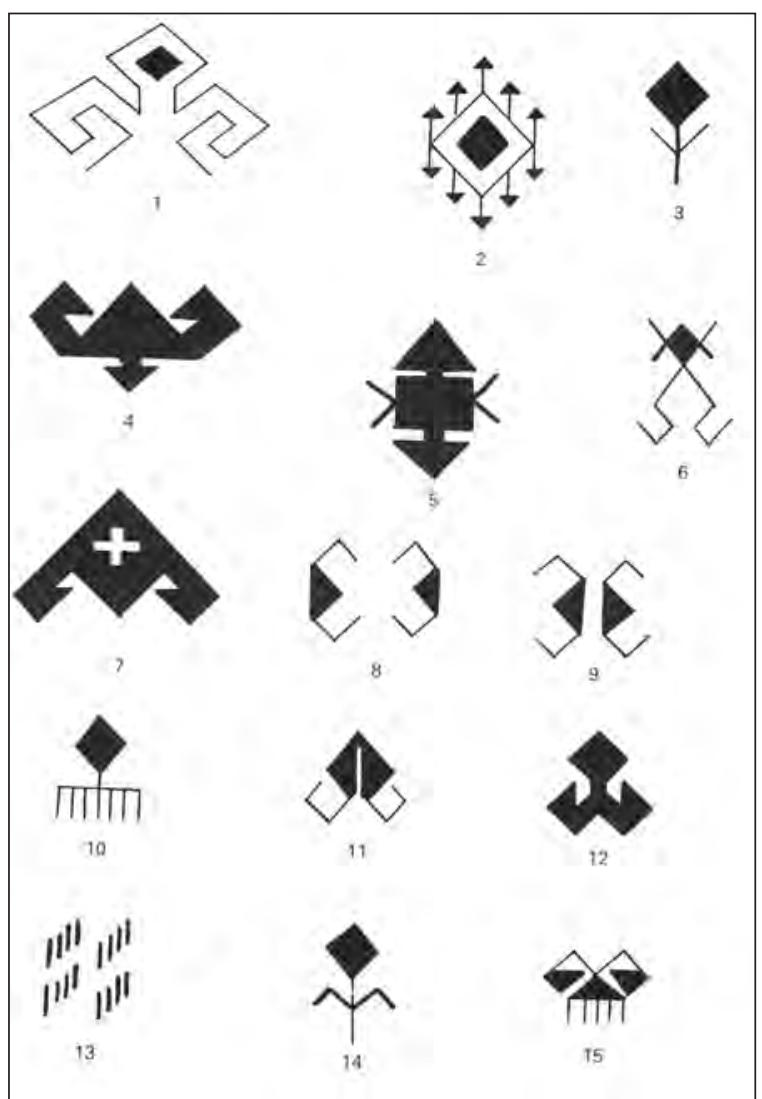

Fig. 10. Semantics of symbols - stylized human figures on Afşar, Turkmen and Yörük kilim (after Durul 1987). From left to right: 1. Strong man; 2. Procession of mounted guards of the bride; 3 . Good omen and prosperity among the Bayat tribe in the Emirdağ region; 4. Strong man; 5. Procession of mounted men protecting the bride; 6. Split legs; 7. Strong man; 8. Offended friends/lovers; 9. Opposition between friends/lowers; 10. Assertive woman; 11. Pregnant woman; 12. Tribal sign of the Dodurga 0̆̆uz; 13. jealousy/gossip; 14. Sign of good omen and prosperity among the Bayat tribe in the Emirdağ region; 15. Split legs.

ronment and reflects to some extent the subsistence activities of the group. Motifs include stylized plants, willow branches, leaves, flowers, pines, bunches of grapes, ears of grain, stacks of grain, etc. Among some tribes, a willow branch represents sorrow.

Geometric and linear patterns constitute the fifth group. Among the designs, continuous vertical lines, meanders and zigzags represent water/streams/rivers. In addition to a diagonal lattice, lozenge, the zigzag pattern termed "cattle's urine path" (Turkish: "sığır sidiği yolu") is quite common among pastoral nomads. For present day Turkmen, Zaza or Kurdish groups in Anatolia this motif describes the environment of camp-sites where herds of cattle moving up and down to pastures in files create narrow paths that are further marked by flows of cattle urine.

It is important to stress that such linear patterns are rather common not only on prehistoric pottery, but also occasionally on wall paintings (e.g. Çatalhöyük). The meaning of such linear compositions among the Neolithic communities of south-eastern Europe or Anatolia can only be guessed.

It is obvious that in each of the five categories there are individual motifs, especially those found on sacks of cereals and on most hanging kilims, that conceptualize good luck, blessing, prospe-

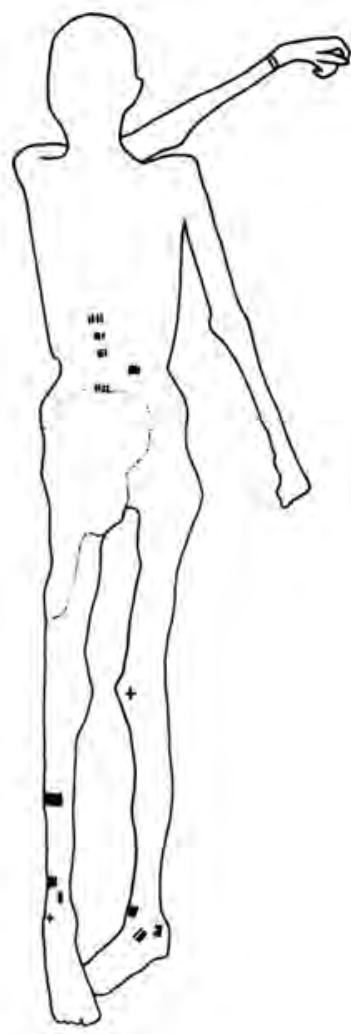

Fig. 11. Tattoos on the body of the Ice Man (Ötzi) (after Spindler 1994).

rity, abundance, love's path, protection from bad luck and evil, etc. A relatively large number of motifs and compositions in all five categories simply

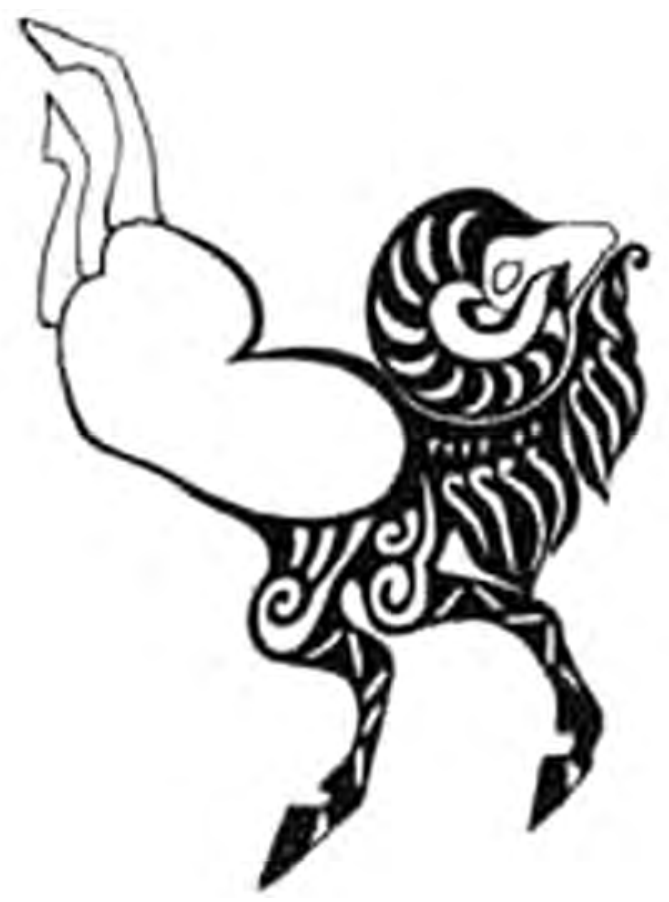

Fig. 12. An animal figure tattooed on the Siberian Scythian burial (after Rudenko 1970). 
depict details in the natural and social environment of the group. In addition, more mundane situations or feelings pertaining to jealousy, or even gossip about family, clan or tribe members, for instance lovers, estranged lovers, or mother's son, are also expressed in symbols 8 .

For tribe or clan members, motifs decorating woven textiles provide a sort of coded language not easily understood by outsiders. For instance, a kilim woven for a bride-to-be, or a new bride on her way to her husband's encampment or village could possess a kind of symbolism not easily understood by those outside her clan. Such kilims and embroideries are of personal value and therefore meticulously kept like cherished documents.

To sum up, ethnographic analogies strongly suggest that also in Neolithic societies susceptibility to the powers of nature would have necessitated the invention of various forms of precautionary measures, some requiring preventive/curative group rituals. An event outside the established order or course of nature would have been treated as "undesirable", "dangerous", or "destructive". Special acts and observances devised to cope with forces of "good" and "evil" must been considered "sacred", and performed according to special codes of behavior. The association of such ceremonial procedures with beliefs in supernatural forces, ancestral spirits, and possibly other kinds of spirits/ghosts would have required the performance of rituals. However, having observed that the performance of cult rituals did not or could not 'always' bring about the desired results in maintaining regularity in natural processes, additional acts of communication, persuasion, magic healing could have been devised and performed. Such ritual acts could also have required the use of objects sanctified by symbols and figures. Since ethnographic studies demonstrate that in animistic societies, animals, plants and objects, being part of peoples' surroundings, possess souls or spirits, we may assume with some confidence that in prehistoric societies certain objects decorated with such motifs would have been considered animated during rituals.

\section{REFERENCES}

ACIPAYAMLI 0. 1978. Les motifs folkloriques Turcs de la pierre et du crane dans la prière pour la pluie. Anthropolgie 8:11-19.

\section{BAMBOROUGH P. 1979. Antique Oriental Rugs and Carpets. Hong Kong.}

BIEHLY P. F. 1996. Symbolic communication systems: Symbol and Anthropomorphic Figurines of the Neolithic and Chalcolithic from South-East Europe. Journal of European Archaeology 4: 162.

BISCHOFF D. 2002. Symbolic worlds of Central and Southeast Anatolia in the Neolithic. In Gérard F. and Thissen L. (eds.), The Neolithic of Central Anatolia. Internal Developments and External Relations during the $9^{\text {th }}-6^{\text {th }}$ Millennia Cal. BC: 237-251.

DEVLET E. 2001. Rock art and the material culture of Siberian and Central Asian shamanism. In Price N. S. (ed.), The Archaeology of Shamanism. Routledge. London, New York: 43-55.
DOWSON T. A. and PORR M. 2001. Special objectsspecial creatures: shamanistic imagery and the Aurignacian art of south-west Germany. In Price N. S. (ed.), The Archaeology of Shamanism. Routledge. London, New York: 165-177.

DURUL Y. 1987. Anadolu Kilimlerinden Örnekler. Istanbul.

HODDER I. 1982. Symbolic and Structural Archaeo$\log y$. Cambridge University Press. Cambridge.

1987. The Archaeology of Contextual Meanings. Cambridge University Press. Cambridge.

1989. The Meanings of Things: Material Culture and Symbolic Expression. Harper Collins. London.

HODDER I. et al. 1995. Interpreting Archaeology: Finding Meanings in the Past. Routledge. London, New York.

8. For details, see Durul (1987.5:8, 17:4, 6:1, 16:5, 22:8, 22:13). 
LEWIS-WILLIAMS J. D. 2001. Southern African shamanistic rock art in its social and cognitive context. In Price N. S. (ed.), The Archaeology of Shamanism. Routledge. London, New York: 17-39.

JORDAN P. 2001. The materiality of shamanism as a 'world view': Praxis, artifacts and landscape. In Price N. (ed.), The Archaeology of Shamanism. Routledge. London, New York: 87- 104.

MALINOWSKI B. 1954. Magic, Science and Religion. New York.

MELLAART J. 1962. Excavations at Çatal Höyük. Anatolian Studies 12:41-65.

1970. Excavations at Hacilar I-II. Edinburgh.

NIKOLOVA L. ed. 2003. Early Symbolic Systems of Communication in Southeast Europe. Volume I. BAR International Series 1139. 0xford.

ÖZTAN A. and ÖZKAN S. 2003. Çizi ve nokta bezeli Köşk Höyük seramikleri. In Özdoğan M., Hauptmann H. and Başgelen N. (eds.), From Villages to Towns. Studies Presented to Ufuk Esin: 447-458.
PESCHLOW-BINDOKAT A. 1995. Ziegenjagd und Kulttans. Die ältesten prähistorischen Felsmalereien in Westkleinasien. Antike Welt 26: 114-117.

2003. Frühe Hochzeitsbilder zur Deutung der Weiblichen Figure auf den prähistorischen Felsbildern des Latmos (Beşparmak). In Özdoğan M., Hauptmann H. and Başgelen N. (eds.), From Villages to Towns. Studies Presented to Ufuk Esin: 199-215.

RUDENKO S. I. 1970. Frozen Tombs of Siberia: The Pazyrk Burials of Iron Age Horsemen. J. M. Dent \& Sons. London.

SPINDLER K. 1994. The Man in the Ice. Phoenix. London.

YAKAR J. 1991. Prehistoric Anatolia: The Neolithic Transformation and the Early Chalcolithic Period. Tel Aviv

2003. Language of Symbols:Communicating with the Supernatural in Prehistoric Anatolia. In Nikolova L. (ed.), Early Symbolic Systems of Communication in Southeast Europe. Volume I. BAR International Series 1139: 25-29. 